\title{
Research
}

\section{Economic Evaluation of Pollination Services Comparing Coffee Landscapes in Ecuador and Indonesia}

\author{
$\underline{\text { Roland Olschewski }}^{1}, \underline{\text { Teja Tscharntke }}{ }^{1}, \underline{\text { Pablo C. Benítez }}{ }^{2}, \underline{\text { Stefan Schwarze }}^{1}$, and $\underline{\text { Alexandra-Maria Klein }}{ }^{1}$
}

\begin{abstract}
Biodiversity conservation through land-use systems on private land is becoming a pressing environmental policy issue. Agroforestry, such as shade-coffee production, contributes to biodiversity conservation. However, falling coffee prices force many coffee growers to convert their sites into economically more attractive land uses. We performed an economic evaluation of coffee pollination by bees in two distinct tropical regions: an area of low human impact with forests neighboring agroforestry in Indonesia and an area of high human impact with little remaining forest in Ecuador. We evaluated bee pollination for different forest-destruction scenarios, where coffee yields depend on forests to provide nesting sites for bees. We used two novel approaches. First, we examined how coffee net revenues depend on the pollination services of adjacent forests by considering berry weight in addition to fruit set, thereby providing a comprehensive evaluation. Second, we determined the net welfare effects of land-use changes, including the fact that former forestland is normally used for alternative crops. In both regions, crop revenues exceeded coffee pollination values, generating incentives to convert forests, even if owners would be compensated for pollination services. The promotion of certified "biodiversity-friendly" coffee is a feasible option to maintain shade-coffee systems. This is of special importance in high-impact areas where only small forest fragments remain. We conclude that a comprehensive economic analysis is necessary to adequately evaluate rainforest preservation for the enhancement of ecosystem services, such as pollination.
\end{abstract}

Key Words: biodiversity conservation; certified shaded coffee; environmental services; pest management

\section{INTRODUCTION}

In contrast to general perception, tropical landscapes are often not covered by continuous natural forests, but consist of a mosaic of different land-use systems. Within such a mosaic, biodiversity conservation through land-use systems on private land is becoming a pressing environmental policy issue (IISD 2005).

Biodiversity-rich land-use systems, such as extensive agroforestry under complex shade, are often practiced in developing countries by smallholders (Perfecto et al. 1996) who use small patches of land to diversify their income sources (Oxfam America 2005). However, the recent price decrease on the world coffee market has caused many producers to abandon their coffee fields and convert this land to produce economically more attractive crops (O'Brien and Kinnaird 2003, Oxfam America 2005, Benítez et al. 2006). The resulting landscape fragmentation leads to both ecological and economic consequences, necessitating an interdisciplinary approach to evaluate possible effects of land-use changes (Balmford et al. 2002, Bawa et al. 2004, du Toit et al. 2004, Gillison et al. 2004, Schroth et al. 2004).

Preservation of biodiversity and related ecosystem services, such as bee pollination, can only be addressed adequately if the local (habitat) management is considered in the context of the surrounding landscape matrix (Daily et al. 1997, Kremen et al. 2004, Kremen 2005). Natural source habitats of plants and animals invading agricultural systems are often particularly important to biodiversity-related ecosystem services (Tscharntke et al. 2005).

The importance of landscape composition for ecosystem services has recently been shown for coffee landscapes, where pollinator activity and 
coffee fruit set are higher in agroforestry sites adjacent to forest fragments (Klein et al. 2003, Ricketts 2004). Although highland coffee, Coffea arabica L., is known as a self-fertile species, previous studies have shown that bee pollination increases fruit set and berry weight, whereas the occurrence of pea-berries (only one bean instead of two beans in one berry) is reduced (Manrique and Thimann 2002, Roubik 2002, Klein et al. 2003, De Marco and Coelho 2004, Ricketts 2004). Many bee species depend on natural habitats, such as forest fragments (Ghazoul et al. 1998, Cunningham 2000, Aizen and Feinsinger 2003); thus, it has been shown that coffee fruit set increases when natural rainforest patches are adjacent to coffee systems (Klein et al. 2003, De Marco and Coelho 2004, Ricketts 2004, Ricketts et al. 2004). In consequence, natural forest ecosystems play an important role for bee pollination services.

Here, we present two novel approaches. First, we analyzed the impact of reduced pollination services on net revenues caused by forest destruction adjacent to coffee agroforestry by accounting for berry weight in combination with fruit set. Second, we determined the net welfare effects of land-use changes, including the fact that former forested land is normally used for alternative crops. Furthermore, we compared the results from study areas in Sulawesi (Indonesia) and southern Manabí (Ecuador), which are characterized, respectively, as an area of low human impact in the neighborhood of a large National Park of continuous near-natural rainforest, and an area of high human impact in a highly fragmented landscape.

\section{METHODS}

The ecological data were collected from December 2000 to January 2001, and from August to October 2001, in 24 agroforestry systems in the area of low human impact in Central Sulawesi, Indonesia $\left(01^{\circ}\right.$ 24' S, 120²0' E; 1224-1299 m) at the southeastern border of the Lore-Lindu National Park, Napu valley, $100 \mathrm{~km}$ southwest of the city of Palu. The sites were selected such that forest distance was not correlated with shade density. In each agroforestry system, flower-visiting bee species were counted, and fruit set after open pollination was determined on four distinct branches of different coffee plants (for detailed information see Klein et al. 2003). Additionally, we randomly collected 50 ripe and 50 overripe berries per site. In the laboratory, fresh weights of all ripe berries from the 24 sites were measured and mean values per site were calculated.

For our economic analysis, we assumed that coffee growers strive to maximize their net revenue, which is defined as the difference between revenues and costs. A decrease in pollination services caused by ongoing destruction of adjacent forest cover affects profits in two ways: first, reduced yields lead to lower gross revenues if the market price remains constant; second, variable harvest and transportation costs decrease. Whereas forest destruction reduces net coffee revenues, preserving forest margins avoids such negative effects. The avoided losses can be assigned to the preserved forest area as a value for maintaining pollination services. Data on Indonesian yields, prices, and production costs were collected during a household survey in 2001, in which 301 randomly selected households were interviewed using standardized, formal questionnaires (for details on the sampling procedure see Zeller et al. 2002).

To compare the economic impact of the ecological changes in different landscapes, we chose southern Manabí in Ecuador $\left(80^{\circ} 35^{\prime} \mathrm{W}, 1^{\circ} 19^{\prime} \mathrm{S} ; 300 \mathrm{~m}\right)$ as a second study area, which was characterized by a high degree of landscape fragmentation with a small number of remaining forest fragments. Our economic analysis was based on published findings from both Latin America (Le Pelley 1968, Ricketts 2004) and Indonesia (Klein et al. 2003) that the ecological mechanisms for coffee pollination services and coffee berry borer infestation are similar in both regions. In Ecuador, we determined net revenues using an economic survey of 100 coffee farmers combined with a time-series analysis of the study region (SICA 2003). In addition, we conducted an economic analysis of the local coffee markets in both regions to predict possible price changes. Based on our ecological results, we used scenarios to determine the regional net welfare effect in cases where the former forestland is converted to alternative crops.

\section{RESULTS}

\section{Pollination services}

The empirical data of the number of flower-visiting bees and their relationship to fruit set showed that: open pollination resulted in significantly higher fruit 
set than bagged pollination; bee diversity was significantly related to coffee fruit set; and average coffee fruit set was negatively correlated with forest distance (Fig. 1A: $\mathrm{y}=85.22-0.64 \mathrm{x}^{0.5}$; compare Klein et al. 2003). Furthermore, average berry weight was negatively correlated with forest distance (Fig. 1B: $y=1.65-0.01 \mathrm{x}^{0.5}$ ). We estimated the economic impact of increased forest distances on pollination services by combining both findings, which implied stronger reduction in pollination services as fruit set decreased and lower weights of resulting fruits. Our economic survey in Sulawesi showed that an extensively managed coffee agroforestry system generated an average annual yield of $269 \mathrm{~kg} / \mathrm{ha}$ of cleaned and dried coffee beans. Gross revenues were 129 USD/ha using an average price of $0.48 \mathrm{USD} / \mathrm{kg}$ (based on survey data, see Table 1).

At a maximum distance of $1500 \mathrm{~m}$, the combined effects resulted in a $45 \%$ reduction in annual yield per hectare (Table 1), whereas the effect of fruit set alone gave a yield decrease of only $29 \%$ per hectare (data not shown). Gross revenues declined by $45 \%$, from 129 to 72 USD/ha; net revenues diminished by $47 \%$, from 100 to 53 USD/ha (Fig. 2A, Table 1). This similar percentage effect on gross and net revenues occurred because lower yields generate lower gross income, as well as lower variable costs, whereas fixed costs play only a minor role in the extensive coffee systems in Sulawesi. However, in absolute terms, there is a considerable difference between gross and net revenue decline, which leads to different pollination values depending on which variable is chosen. Additionally, we calculated the marginal (net) revenue decrease when forest distance increased in 100-m steps. The main effect on yields (about $55 \%$ of the overall reduction) took place within a distance of $400 \mathrm{~m}$ from adjacent forests (Fig. 2B).

According to Ricketts (2004), similar effects of forest distance also occur in other tropical coffee regions, such as Latin America. This motivated us to compare the economic results from the Indonesian low-impact study area with a highly fragmented region in Ecuador. Here, coffee is usually not cleaned, but is sold as dried berries without further processing. This results in an average annual coffee yield of about $850 \mathrm{~kg} / \mathrm{ha}$; however, to make this figure comparable with those from Indonesia, a conversion factor of 0.2 must be applied, giving an equivalent of $170 \mathrm{~kg} / \mathrm{ha}$ of dried and cleaned beans. Using the Ecuadorian long-term average price of $0.2 \mathrm{USD} / \mathrm{kg}$ of dried coffee berries (SICA 2003), gross revenues were $171 \mathrm{USD} / \mathrm{ha}$. At a maximum distance of $1500 \mathrm{~m}$, yields and gross revenues declined by $45 \%$, whereas net revenues were reduced by $93 \%$, from 52 to 3 USD/ha, i.e., by far more than expected when examining yields or gross revenue reduction alone. As yields declined, variable harvesting and transportation costs were also reduced, but because of more intensive management (with a higher percentage of fixed costs for cleaning, pruning, and shadow control), net revenues declined at a higher rate than in Sulawesi. As a result, increased distances to forests led to the substantially diminished attractiveness of coffee production (Fig. 2C, D). Additional calculations based on the even lower average coffee prices over the last 5 years resulted in negative net revenues per hectare, forcing many coffee growers to reduce management intensity or to switch to other land-use systems, such as maize or rice production.

\section{Economic impact of deforestation on pollination services}

Based on our findings concerning fruit set and berry weight, we calculated the economic impact on coffee sites with increasing distance from a 100-ha circular forest area. For this purpose, the coffee area around the forest was divided into four $100 \mathrm{~m}$ wide concentric circles (adding up to $192 \mathrm{ha}$ ), where net coffee revenues depended on forest distance (see Table 2). We used this as a reference scenario for comparison with the effects of forest destruction (Fig. 3A) and assumed, in a first step, that a $100 \mathrm{~m}$ wide area of forest margin was destroyed, i.e., the forest area was diminished from 100 to $68 \mathrm{ha}$, resulting in coffee sites located $100 \mathrm{~m}$ from the forest. In Sulawesi, the average net revenues of the adjacent coffee area (192 ha) were reduced by $7 \%$, from 85 to 79 USD/ha, because of the increased distance to the remaining forest (see Table 3, column 1 ; note that these figures refer to net revenues per hectare, calculated as the average of the four rings, i.e., 16,347 USD/192 ha $=85$ USD/ha). Destroying the first $100 \mathrm{~m}$ of forest margin led to reduced average net revenues in this same (constant) coffee area (15,214 USD/192 ha =79 USD/ha). In Manabí, net revenues declined from 36 to $30 \mathrm{USD} / \mathrm{ha}$, which reflected a reduction of about $17 \%$. The corresponding results in cases where further $100-\mathrm{m}$ strips of forest margin were converted stepwise are shown in Table 3 and Fig. 3B. Finally, we considered the extreme situation where the 100-ha 
Fig. 1. Coffee fruit set and berry weight in relation to forest distance. (A) Mean fruit set of coffee plants in each of 24 agroforestry systems in relation to the distance to continuous forest $\left(\mathrm{y}=85.22-0.64 \mathrm{x}^{0.5} ; F\right.$ $=11.83, R=-0.59, N=24, P=0.0023$ ). (B) Mean coffee berry weight of 50 randomly sampled ripe coffee berries from each of 24 agroforestry systems in relation to the distance to continuous forest $(\mathrm{y}=1.65-$ $\left.0.01 \mathrm{x}^{0.5} ; F=4.70, R=-0.42, N=24, P=0.0413\right)$.
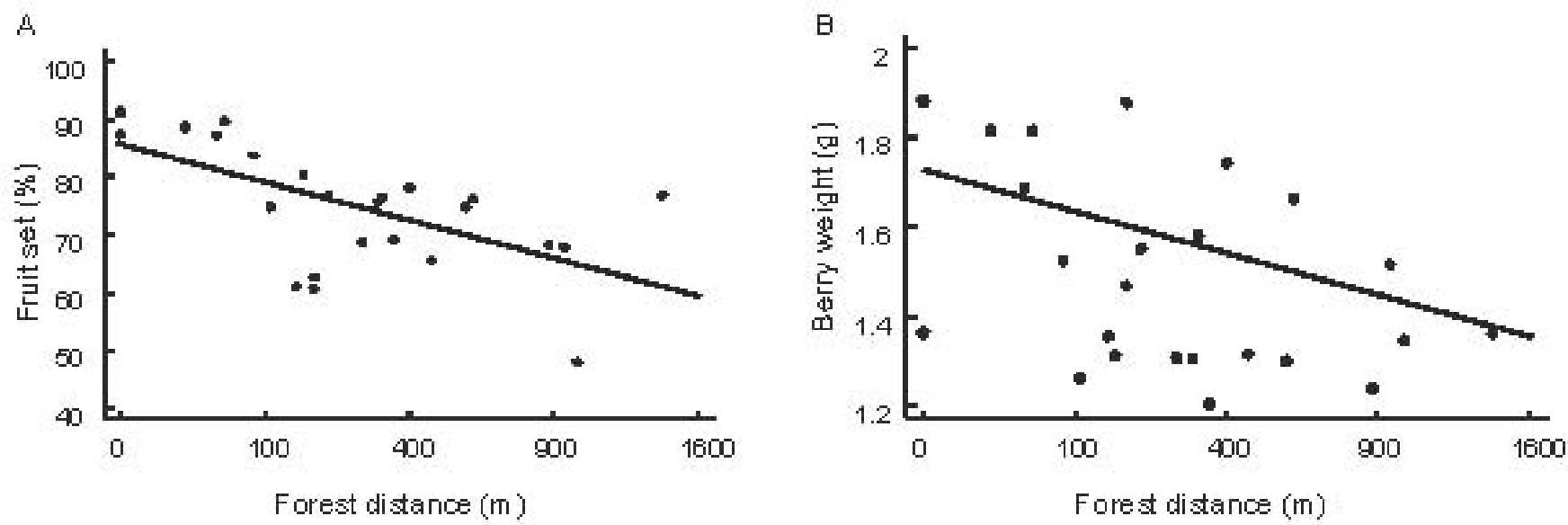

forest area was completely destroyed. In this case, we assumed that coffee sites received only minor pollination services from other forest patches within about $1000 \mathrm{~m}$ (compare Table 1). Complete forest destruction reduced average net revenues by $28 \%$, to $61 \mathrm{USD} / \mathrm{ha}$, in Sulawesi, whereas in Manabí, the decline was about $70 \%$, to $11 \mathrm{USD} / \mathrm{ha}$.

In the case where the forest was not destroyed, the value of pollination services can be calculated by assigning the avoided coffee net revenue loss to the forest area conserved. In contrast to the substantial differences in the country-specific relative changes, the absolute value of pollination services was similar in both countries. Deforestation of the first $100 \mathrm{~m}$ (32 ha) would reduce the total net revenue in the adjacent coffee area from 16,347 to 15,214 USD in Sulawesi, and from 7005 to 5825 USD in Manabí. Preserving the forest avoids a net coffee revenue reduction of 1133 and 1180 USD in Sulawesi and Manabí, respectively. Thus, the average pollination value assigned to the 32 ha of forest margin amounts to $35 \mathrm{USD} /$ ha of forest in Indonesia and $36 \mathrm{USD} / \mathrm{ha}$ in Ecuador. Complete deforestation (100 ha) would lead to a pollination service loss of $47 \mathrm{USD} / \mathrm{ha}$ of forest in Indonesia and $49 \mathrm{USD} / \mathrm{ha}$ in Ecuador (Table 3).

\section{Net welfare effect of deforestation, including alternative crops}

When determining the value of forest patches for coffee production, we assumed that an existing forest area was partly or entirely destroyed. The resulting net revenue reductions in the coffee area were assigned to the deforested area and the respective value per hectare reflects the positive economic effect of pollination services when maintaining the forest. This procedure neglects the fact that the former forestland would generally be used for crop production or pasture, thus generating income that would be forgone if the forest were maintained.

Consequently, the net income reduction for coffee farmers (on 192 ha) should be compared with the net income increase generated on the deforested land $(32,58,78$, or 100 ha, respectively; Table 3 , columns 2 and 4). For this purpose, we conducted cost-benefit analyses of alternative land uses, such as maize, rice, and pasture. In both countries, we found that the best alternative land-use systems exceeded the value of pollination services lost by forest destruction. In Sulawesi, net revenues for maize (160 USD/ha) were substantially higher than 
Table 1. Yield and net revenues of coffee systems in Indonesia depending on the distance to adjacent forest patches. All monetary values are in USD.

\begin{tabular}{|c|c|c|c|c|c|}
\hline \multirow{2}{*}{$\begin{array}{l}\text { Distance } \\
\text { (m) }\end{array}$} & \multicolumn{2}{|c|}{ Yield } & \multirow{2}{*}{$\begin{array}{c}\text { Gross revenues } \\
\text { (\$/ha) }\end{array}$} & \multirow{2}{*}{$\begin{array}{l}\text { Costs } \\
(\$ / \mathrm{ha})\end{array}$} & \multirow{2}{*}{$\begin{array}{c}\text { Net revenues } \\
\text { (\$/ha) }\end{array}$} \\
\hline & $(\%) \dagger$ & $(\mathrm{kg} / \mathrm{ha}) \ddagger$ & & & \\
\hline 0 & 100 & 269 & 129 & 29 & 100 \\
\hline 100 & 87 & 235 & 113 & 26 & 87 \\
\hline 200 & 82 & 221 & 106 & 25 & 81 \\
\hline 300 & 79 & 211 & 101 & 24 & 77 \\
\hline 400 & 75 & 203 & 97 & 23 & 74 \\
\hline 500 & 73 & 196 & 94 & 22 & 71 \\
\hline 600 & 70 & 189 & 91 & 22 & 69 \\
\hline 700 & 68 & 184 & 88 & 21 & 67 \\
\hline 800 & 66 & 178 & 86 & 21 & 65 \\
\hline 900 & 64 & 173 & 83 & 20 & 63 \\
\hline 1000 & 63 & 169 & 81 & 20 & 61 \\
\hline 1100 & 61 & 164 & 79 & 20 & 59 \\
\hline 1200 & 60 & 160 & 77 & 19 & 58 \\
\hline 1300 & 58 & 156 & 75 & 19 & 56 \\
\hline 1400 & 57 & 153 & 73 & 19 & 55 \\
\hline
\end{tabular}




\begin{tabular}{|c|c|c|c|c|c|}
\hline 1500 & 55 & 149 & 72 & 18 & 53 \\
\hline $\begin{array}{l}\% \text { change }(0-1500 \\
\text { m) }\end{array}$ & -45 & -45 & -45 & -38 & -47 \\
\hline
\end{tabular}

$\dagger$ Data based on Klein et al. 2003 and our results concerning berry weight (see Fig. 1). A yield of 100\% is reflected by a combination of maximum fruit set $(85.22 \%)$ and berry weight $(1.65 \mathrm{~g} / \mathrm{berry})$.

\$leaned and dried coffee beans.

the average pollination service value of 47 USD/ha for forestland. The same holds for Manabí for net revenues for maize (108 USD/ha; Benítez et al. 2006). In contrast, alternatives, such as rice or pasture, which only achieve levels between 53 and $57 \mathrm{USD} / \mathrm{ha}$, are closer to the average value of 49 $\mathrm{USD} / \mathrm{ha}$ generated by the pollination services of forests.

Summing the reduced net coffee revenues and the additional net crop revenues after deforestation leads to a positive net welfare effect in both study regions. The net welfare in the overall area (292 ha) increased by $69 \%$ in Sulawesi, from 16,347 to 27,697 USD, and by $84 \%$ in Ecuador, from 7005 to 12,911 USD (Table 3).

\section{DISCUSSION}

Our results show that the determination of pollination values should be based on an integrated ecological and economic approach to avoid overor underestimation. Furthermore, the net welfare effect of land-use changes, including revenues from alternative crops on former forestland, must be taken into account.

\section{Combined effect of fruit set and berry weight}

In contrast to previous pollination service studies on coffee (Roubik 2002, Klein et al. 2003), we did not exclusively focus on fruit set or berry weight, but combined the findings concerning fruit set and berry weight in an integrated approach. Calculations based on fruit set alone may either over- or underestimate pollination service values. An overestimation may result from the assumption that fruit set corresponds directly to the quantity of coffee beans harvested later. However, Ricketts et al. (2004) showed that, for combined fruit set and seed mass, adequate pollination in sites far from forested land would increase coffee yields by $20.8 \%$, in contrast with $11.5 \%$ for fruit set alone. Combining both effects results in yield estimates that build a comprehensive basis for the evaluation of pollination services. However, a comprehensive evaluation procedure should include more aspects than just multiplying the respective yields by market prices.

\section{Net revenues and market price changes}

Coffee growers are interested in net revenues (i.e., profits), rather than gross revenues because the former reflect the actual net contribution to household incomes (Gobbi 2000). This should be taken into account when evaluating bee pollination as an ecosystem service (Ricketts et al. 2004). In the Indonesian case, an analysis based on the contribution to gross revenues would lead to average pollination values of 43-57 USD/ha of deforested area (depending on the extent of forest destruction), which reflects an overestimation of about $23 \%$ compared to the results based on net revenues. In Ecuador, the distorting effect would be even stronger and result in pollination values of 57$76 \mathrm{USD} /$ ha of deforested area, i.e., about $57 \%$ higher than when calculated based on net revenues.

Additionally, the final effect on producers' profits depends on the demand side of the product market, where possible price changes must be considered. 
Fig. 2. Coffee revenues in relation to forest distance in Indonesia and Ecuador. (A) and (C), net revenues calculated as revenues minus costs for the combined effect of fruit set and berry weight (see Table 1); (B) and (D), marginal (net) revenue decline calculated as the (net) revenue reduction caused by 100-m stepwise increases in forest distance. All monetary values in USD.
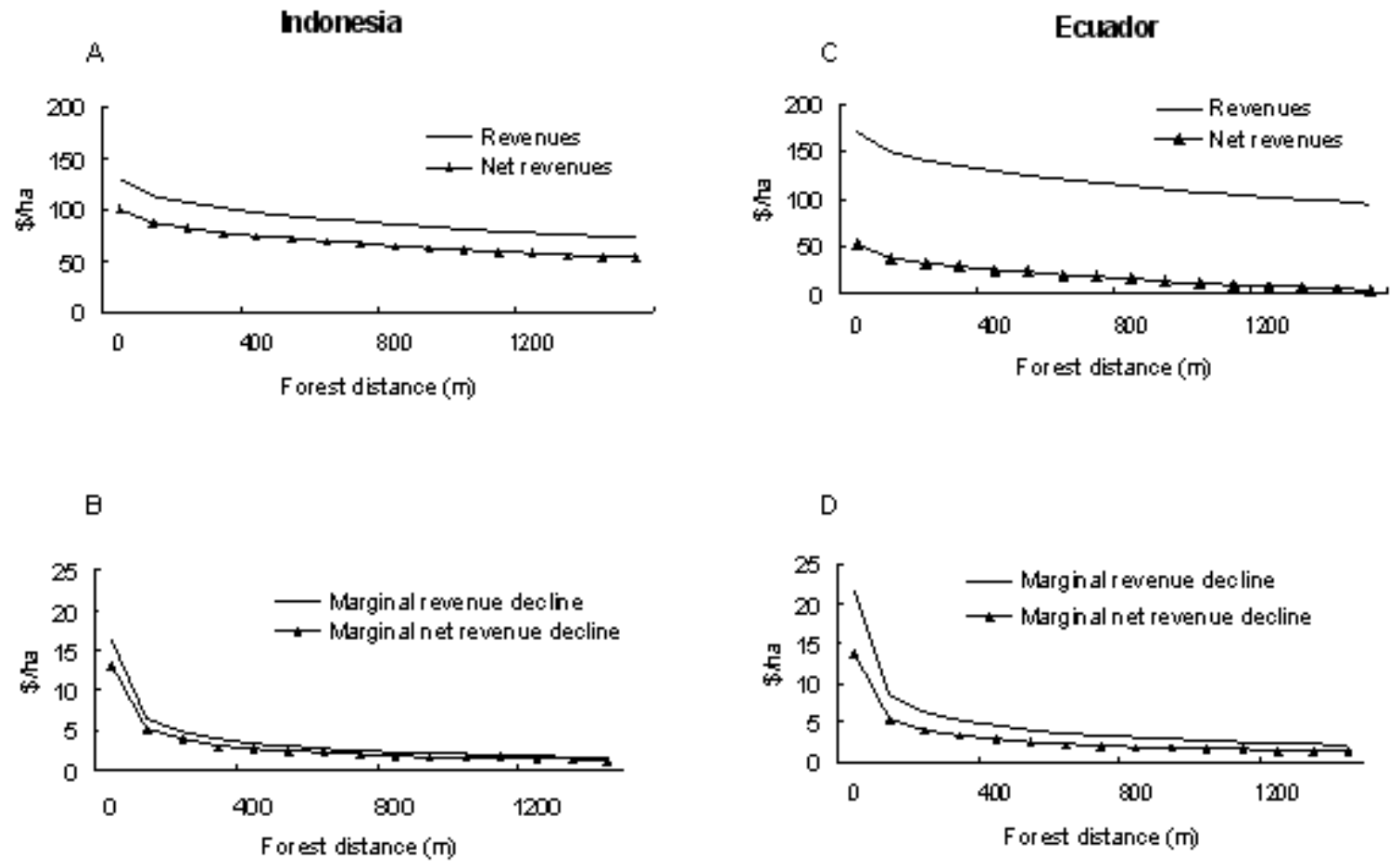

Southwick and Southwick (1992) emphasized this aspect, which, nevertheless, is often neglected when analyzing the positive impact of pollination services (see Ricketts et al. 2004).

Although coffee is a commodity traded at a global level and changes in the supply of a small country will not influence the global coffee price, local prices could still be affected. If increasing numbers of coffee growers reduce their supply when faced with declining revenues, the traded quantity decreases, possibly leading to a price increase on the local market (Kevan and Phillips 2001).

Our market analyses showed that coffee markets in our study regions can be characterized as local monopsonies with many producers on the supply side, most of which hold coffee sites of $<5$ ha and contribute just a small part of the traded quantity. On the demand side, there is often only one single buyer, who has the power to set the price and buys coffee beans or berries directly from producers at the farm gate. We found that supply reductions corresponding to our deforestation scenarios are unlikely to have an impact on local coffee market prices. However, deforestation on a larger scale may cause prices to increase because of a stronger supply reduction; in this case, a calculation based on constant coffee prices would overestimate the net revenue cutbacks caused by reduced pollination services. 
Table 2. Yield and net revenues of coffee systems in Ecuador depending on the distance to adjacent forest patches. All monetary values in USD.

\begin{tabular}{|c|c|c|c|c|c|}
\hline \multirow{2}{*}{$\begin{array}{l}\text { Distance } \\
\text { (m) }\end{array}$} & \multicolumn{2}{|c|}{ Yield } & \multirow{2}{*}{$\begin{array}{c}\text { Gross revenues } \\
\text { (\$/ha) }\end{array}$} & \multirow{2}{*}{$\begin{array}{l}\text { Costs } \\
(\$ / \mathrm{ha})\end{array}$} & \multirow{2}{*}{$\begin{array}{c}\text { Net revenues } \\
\text { (\$/ha) }\end{array}$} \\
\hline & $(\%) \dagger$ & $(\mathrm{kg} / \mathrm{ha}) \ddagger$ & & & \\
\hline 0 & 100 & 853 & 171 & 119 & 52 \\
\hline 100 & 87 & 745 & 149 & 111 & 38 \\
\hline 200 & 82 & 702 & 140 & 108 & 33 \\
\hline 300 & 79 & 670 & 134 & 105 & 28 \\
\hline 400 & 75 & 643 & 129 & 104 & 25 \\
\hline 500 & 73 & 621 & 124 & 102 & 22 \\
\hline 600 & 70 & 600 & 120 & 100 & 20 \\
\hline 700 & 68 & 582 & 116 & 99 & 17 \\
\hline 800 & 66 & 565 & 113 & 98 & 15 \\
\hline 900 & 64 & 549 & 110 & 97 & 13 \\
\hline 1000 & 63 & 535 & 107 & 96 & 11 \\
\hline 1100 & 61 & 521 & 104 & 95 & 10 \\
\hline 1200 & 60 & 508 & 102 & 94 & 8 \\
\hline 1300 & 58 & 496 & 99 & 93 & 6 \\
\hline 1400 & 57 & 484 & 97 & 92 & 5 \\
\hline 1500 & 55 & 473 & 95 & 91 & 3 \\
\hline
\end{tabular}




$\begin{array}{ccccc}\% \text { change }(0-1500 & -45 & -45 & -45 & -23\end{array}$

$\dagger$ Data based on Klein et al. 2003 and our results concerning berry weight (see Fig. 1). A yield of 100\% is reflected by a combination of maximum fruit set $(85.22 \%)$ and berry weight $(1.65 \mathrm{~g} / \mathrm{berry})$. $\ddagger$ Dried coffee berries.

\section{Regional net welfare effects}

Destroying forests adjacent to coffee systems reduces pollination services. This effect has been evaluated in previous studies (Klein et al. 2003, Ricketts et al. 2004). Normally, however, the former forestland will not be abandoned, but used for other crops or pasture; this is often neglected. We accounted for possible revenues of such alternatives to calculate the regional net welfare effect of landuse changes.

Provided that the alternative crop production is sustainable, our results show that it is reasonable for landowners to convert their forestland to other crops because forest conservation would lead to a welfare loss. Even in the case where coffee growers would be willing to compensate forest owners for their pollination services, an incentive for deforestation remains.

A critical question is whether this result holds, even in the case where only small patches of forest remain. Thus, we considered the marginal net welfare effect of gradually deforesting a whole forest area, assuming that the most profitable alternative land-use system was applied. We found that deforestation led to a positive welfare effect, but this effect decreased as more forest was replaced by the alternative crop (Fig. 4 and Table 3). Not surprisingly, the additional welfare generated by the destruction of the first $100 \mathrm{~m}$ of forest margin in Indonesia (125 USD) was higher than in Ecuador (71 USD) because of a moderate net coffee revenue decline and higher net maize revenues per hectare in that region. Interestingly, it remained at this level with stepwise deforestation. Only in the case where the last 22 ha of forest were converted did the marginal welfare effect decrease. In Ecuador, it even became zero, which indicates that maintaining this forest patch would have the same welfare effect for pollination services as for using the land for maize production. Converting the forest to less attractive land-use systems, such as pasture or rice, would lead to a net welfare loss. This result emphasizes the importance of the ecological and economic contributions of small forest remnants in highly fragmented landscapes.

\section{Shade-coffee certification}

Given this situation, the question arises whether coffee systems themselves can take over conservation tasks within a landscape mosaic. Philpott and Dietsch (2003) and Dietsch et al. (2004) showed that shaded coffee systems can contribute significantly to conservation goals, especially when combined with organic and fair-trade certification. However, Perfecto et al. (2005) argued that an additional high price premium that goes directly to the producers would be necessary to make conservation through shade-coffee systems a viable option for land owners. In fact, Benítez et al. (2006), who compared land uses by including price and yield risks, concluded that without considerable payments by certification programs, it is questionable whether biodiversity-rich shadecoffee systems could be prevented from conversion to economically more attractive land uses.

\section{CONCLUSIONS}

As natural habitat for bee populations, forests provide pollination services to adjacent coffee areas. The value of these services can be determined by comparing forest destruction scenarios with a reference situation, where coffee yields depend on the distance to forests. We found that the main economic impact, measured as net revenue per hectare, takes place within a distance of $400 \mathrm{~m}$ of 
Fig. 3. Coffee-growing area and deforestation scenarios. Comparison of (A) 100-ha and (B) 22-ha forest remnants; the surrounding circular areas indicate increasing distances to the central forest area (the width of one ring is $100 \mathrm{~m}$ ). The figure is drawn to scale. We calculated the effect of forest distance on agroforestry systems situated within these rings (100-400-m distances). The extent of gray shading reflects the decline in pollination services; white areas indicate the replacement of forest by alternative cropping.
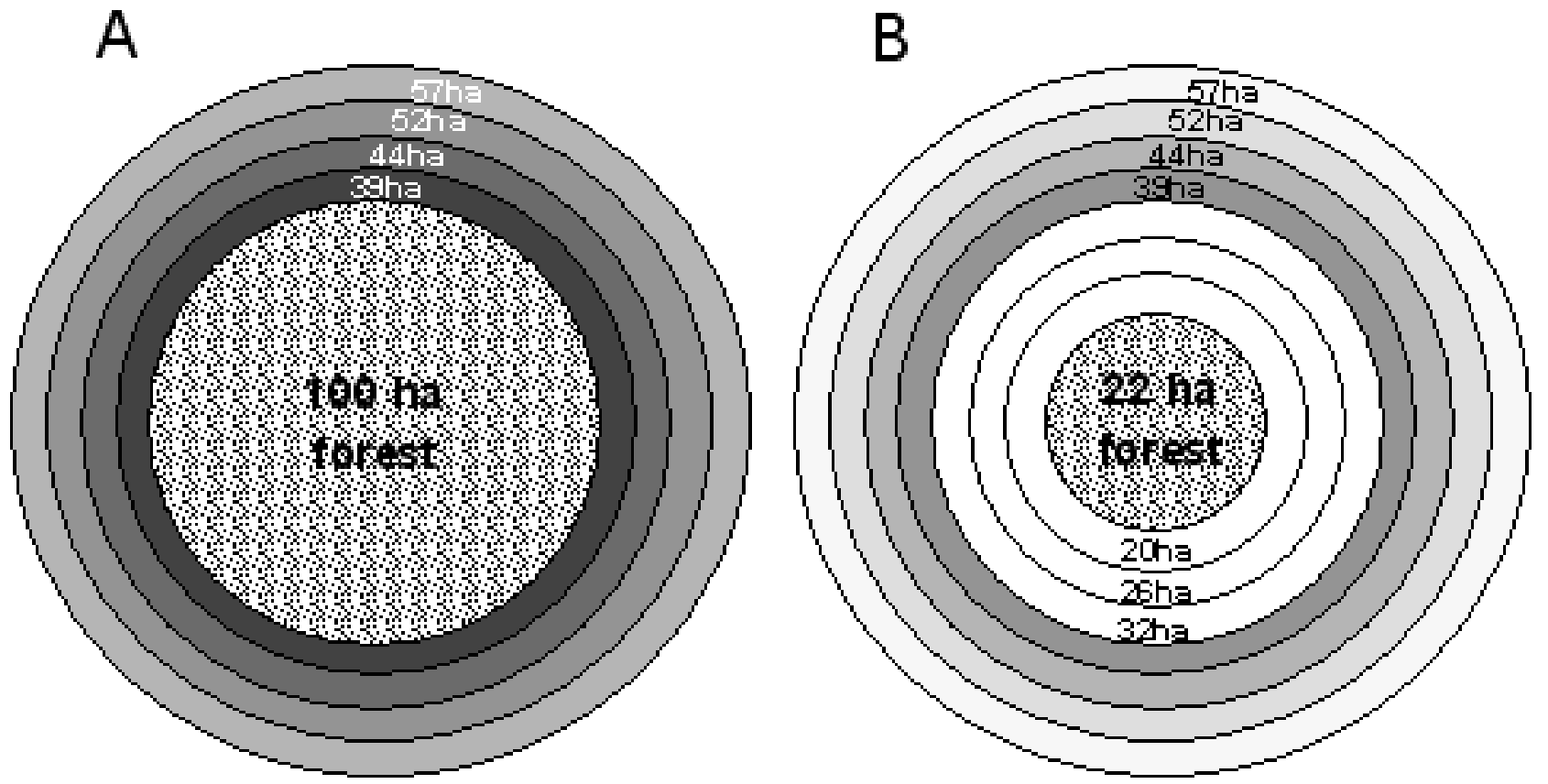

forest patches and is highly influenced by the management system. The Indonesian case study showed a moderate decline in net coffee revenues because of an extensive management system. In Ecuador, more intensive coffee management, including a higher percentage of fixed costs, caused a steep decline in net revenues when adjacent forests were destroyed. Nevertheless, the absolute value of pollination services is similar in both regions.

Our scenarios in both countries show that most landuse alternatives generate higher net revenues per hectare than the value of pollination services assigned to the deforested area. Consequently, from a private landowner's point of view, there is a strong incentive to convert forests into cropland. Even payments for ecosystem services, if based on pollination services alone, would hardly be sufficient to reduce pressure on forest margins. However, further ecosystem services provided by the forest, such as biodiversity and soil conservation, should be taken into account when deciding for or against forest conservation.

Producing certified organic coffee under complex shade could be a possible solution for coffee growers confronted with the impact of adjacent forest site destruction and falling coffee prices on the world market. However, only an elevated consumer willingness to pay for "biodiversityfriendly" coffee would generate substantial incentives for landowners to maintain their shadecoffee production systems, thereby conserving ecological functions, which are of special importance in highly fragmented areas where only small patches of natural forest remain.

Responses to this article can be read online at: http://www.ecologyandsociety.org/voll1/iss 1/art7/responses/ 
Table 3. Economic impact of deforestation on coffee sites and overall welfare. Scenarios are as in Fig. 3; all monetary values are in USD.

\begin{tabular}{|c|c|c|c|c|c|c|c|}
\hline & \multicolumn{2}{|c|}{$\begin{array}{c}\text { Average net } \\
\text { revenue in } \\
\text { coffee-growing } \\
\text { area } \dagger\end{array}$} & \multirow{2}{*}{$\begin{array}{l}\text { Total net } \\
\text { revenue in } \\
\text { coffee-growing } \\
\text { area (192 ha) }\end{array}$} & \multirow{2}{*}{$\begin{array}{c}\begin{array}{c}\text { Average pollination } \\
\text { value of } \\
\text { deforested area } \neq\end{array} \\
(\$ / \mathrm{ha})\end{array}$} & \multirow{2}{*}{$\begin{array}{l}\text { Total net revenue of } \\
\text { alternative crops in } \\
\text { deforested area }\end{array}$} & \multirow{2}{*}{$\begin{array}{l}\text { Net welfare } \\
\text { effect in } \\
\text { overall area } \\
(292 \text { ha) }\end{array}$} & \multirow{2}{*}{$\begin{array}{c}\text { Marginal net } \\
\text { welfare effect in } \\
\text { overall area ( } 292 \\
\text { ha) }\end{array}$} \\
\hline $\begin{array}{l}\text { INDONESIA } \\
\text { Deforested area } \\
\quad \text { (ha) }\end{array}$ & (\$/ha) & $(\%)$ & & & & & \\
\hline 0 & 85 & 100 & 16,347 & 0 & 0 & 16,347 & 0 \\
\hline 32 & 79 & 93 & 15,214 & 35 & 5120 & 20,334 & 3987 \\
\hline 58 & 76 & 89 & 14,510 & 31 & 9280 & 23,790 & 3456 \\
\hline 78 & 73 & 85 & 13,928 & 31 & 12,480 & 26,408 & 2618 \\
\hline $100 \S$ & 61 & 72 & 11,697 & 47 & 16,000 & 27,697 & 1289 \\
\hline \multicolumn{8}{|l|}{$\begin{array}{l}\text { ECUADOR } \\
\text { Deforested area } \\
\text { (ha) }\end{array}$} \\
\hline 0 & 36 & 100 & 7005 & 0 & 0 & 7005 & 0 \\
\hline 32 & 30 & 83 & 5825 & 36 & 3456 & 9281 & 2276 \\
\hline 58 & 27 & 73 & 5092 & 33 & 6264 & 11,356 & 2075 \\
\hline 78 & 23 & 64 & 4485 & 32 & 8424 & 12,909 & 1554 \\
\hline $100 \S$ & 11 & 30 & 2111 & 49 & 10,800 & 12,911 & 2 \\
\hline
\end{tabular}

$\dagger$ Mean net revenue per hectare in the 192-ha coffee-growing area (see Tables 1 and 2) declines with increasing distance to the forest.

$\ddagger$ Calculated by assigning the reduction in total net coffee revenues to the number of hectares deforested. $\S$ In the case where the forest is completely destroyed, we assumed that coffee sites received only minor pollination services from other forest patches within about $1000 \mathrm{~m}$. 


\section{Acknowledgments:}

Financial support was provided by the German Federal Ministry of Education and Research (BMBF, BioTEAM program) and the German Research Foundation (DFG, Collaborative Research Center SFB 552).

\section{LITERATURE CITED}

Aizen, M. A., and P. Feinsinger. 2003. Bees not to be? Responses of insect pollinator faunas and flower pollination to habitat fragmentation. Pages 111-129 in G. A. Bradshaw and P. A. Marquet, editors. How landscapes change: human disturbance and ecosystem fragmentation in the Americas. Ecological Studies, volume 162. Springer-Verlag, Berlin, Germany.

Balmford, A., A. Bruner, P. Cooper, R. Costanza, S. Farber, R. E. Green, M. Jenkins, P. Jefferiss, V. Jessamy, J. Madden, K. Munro, N. Myers, S. Naeem, J. Paavola, M. Rayment, S. Rosendo, J. Roughgarden, K. Trumper, and R. K. Turner. 2002. Economic reasons for conserving wild nature. Science 297:950-953.

Bawa, K. S., W. J. Kress, N. M. Nadkarni, S. Lele, P. H. Raven, D. H. Janzen, A. E. Lugo, P. S. Ashton, and T. E. Lovejoy. 2004. Tropical ecosystems into the $21 \mathrm{st}$ century. Science 306:227-228.

Benítez, P. C., T. Kuosmanen, R. Olschewski, and G. C. van Kooten. 2006. Conservation payments under risk: a stochastic dominance approach. American Journal of Agricultural Economics $\mathbf{8 8}$ (1):1-15.

Cunningham, S. A. 2000. Depressed pollination in habitat fragments causes low fruit set. Proceedings of the Royal Society of London, Series B 267:1149-1152.

Daily, G. C., S. Alexander, P. R. Ehrlich, L. Goulder, J. Lubchenco, P. A. Matson, H. A. Mooney, S. Postel, S. H. Schneider, D. Tilman, and G. M. Woodwell. 1997. Ecosystem services: benefits supplied to human societies by natural ecosystems. Issues in Ecology 2:1-16.

De Marco, P., and F. M. Coelho. 2004. Services performed by the ecosystem: forest remnants influence agricultural cultures' pollination and production. Biodiversity and Conservation 13:1245-1255.

Dietsch, T. V., S. M. Philpott, R. A. Rice, R. Greenberg, P. Bichier, T. G. O'Brien, and M. F. Kinnaird. 2004. Conservation policy in coffee landscapes. Science 303:625-626.

du Toit, J. T., B. H. Walker, and B. M. Campbell. 2004. Conserving tropical nature: current challenges for ecologists. Trends in Ecology and Evolution 19:12-17.

Ghazoul, J., K. A. Liston, and T. J. B. Boyle. 1998. Disturbance-induced density-dependent seed set in Shorea siamensis (Dipterocarpaceae), a tropical forest tree. Journal of Ecology 86:462-473.

Gillison, A. N., N. Liswanti, S. Budidarsono, M. van Noordwijk, and T. P. Tomich. 2004. Impact of cropping methods on biodiversity in coffee agroecosystems in Sumatra, Indonesia. Ecology and Society 9(2):7. [online] URL: http://www.ecologya ndsociety.org/vol9/iss2/art7.

Gobbi, J. A. 2000. Is biodiversity-friendly coffee financially viable? An analysis of five different coffee production systems in western El Salvador. Ecological Economics 33:267-281.

IISD. 2005. Biodiversity: science and governance. Summary report of the International Scientific Conference 24-28 January 2005 in Paris. International Institute for Sustainable Development. [online] URL: http://www.iisd.ca/sd/icb.

Kevan, P. G., and T. P. Phillips. 2001. The economic impacts of pollinator declines: an approach to assessing the consequences. Conservation Ecology 5(1):8 [online] URL: http://www.consecol. org/vol5/iss1/art8.

Klein, A.-M., I. Steffan-Dewenter, and T. Tscharntke. 2003. Fruit set of highland coffee increases with the diversity of pollinating bees. Proceedings of the Royal Society of London, Series $B$ 270:955-961.

Kremen, C. 2005. Managing ecosystem services: 
Fig. 4. Marginal net welfare effect per hectare of deforested land. We assumed that 100 ha of forest were converted stepwise $(32,26,20$, and 22 ha) into maize (see also Fig. 3B and Table 2). The marginal net welfare effect combines additional net revenues from maize production and reduced coffee revenues caused by diminished pollination services. Monetary values are in USD.

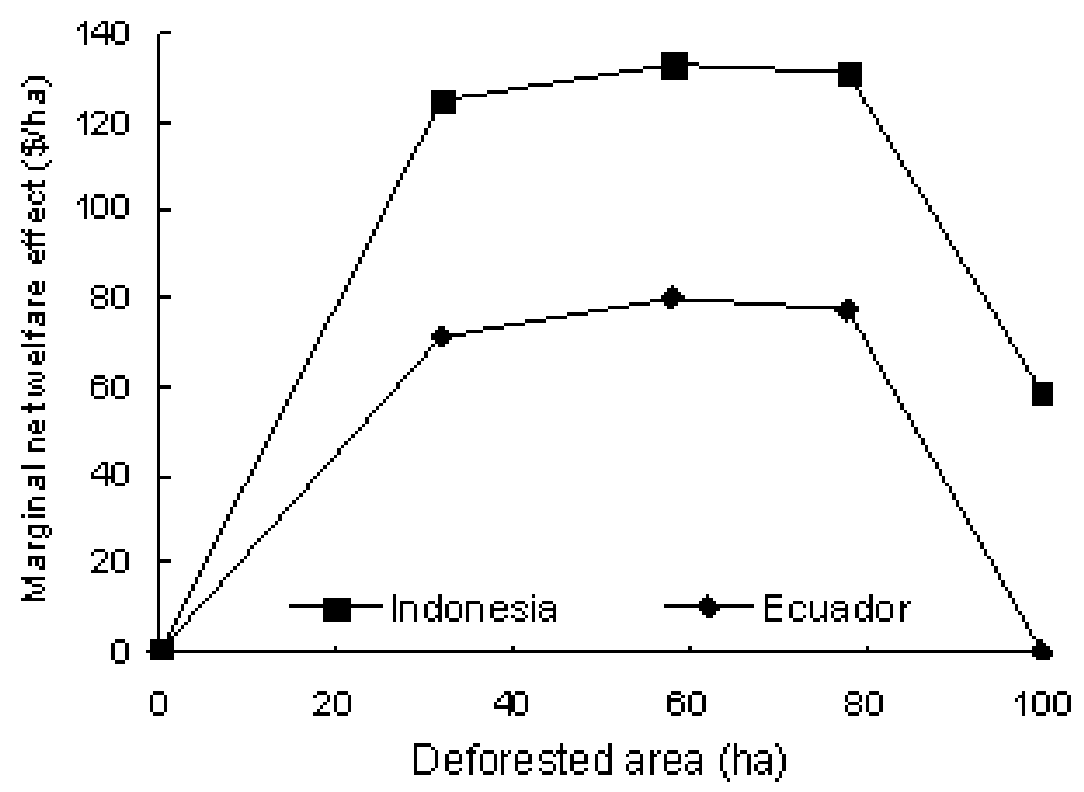

what do we need to know about their ecology. Ecology Letters 8:468-479.

Kremen, C., N. M. Williams, R. L. Bugg, J. P. Fay, and R. W. Thorp. 2004. The area requirements of an ecosystem service: crop pollination by native bee communities in California. Ecology Letters 7:1109-1119.

Le Pelley, R. H. 1968. Pests of coffee. Tropical Science Series. Longmans, Green and Co., London, UK.

Manrique, A. J., and R. E. Thimann. 2002. Coffee (Coffea arabica) pollination with africanized honeybees in Venezuela. Interciencia 27:414-416.

O'Brien, T. G., and M. F. Kinnaird. 2003. Caffeine and conservation. Science 300:587.
Oxfam America. 2005. The coffee crisis continues. Situation assessment and policy recommendations for reducing poverty in the coffee sector. Oxfam America. [online] URL: http://www.oxfamamerica. org/crisis continues.

Perfecto, I., R. A. Rice, R. Greenberg, and M. E. Van der Voort. 1996. Shade coffee: a disappearing refuge for biodiversity. Bioscience 46:598-608.

Perfecto, I., J. Vandermeer, A. Mas, and L. Soto Pinto. 2005. Biodiversity, yield, and shade coffee certification. Ecological Economics 54:435-446.

Philpott, S. M., and T. Dietsch. 2003. Coffee and conservation: a global context and the value of farmer involvement. Conservation Biology 17:1844-1846.

Ricketts, T. H. 2004. Tropical forest fragments enhance pollinator activity in nearby coffee crops. 
Conservation Biology 18:1262-1271.

Ricketts, T. H., G. C. Daily, P. R. Ehrlich, and C. D. Michener. 2004. Economic value of tropical forest to coffee production. Proceedings of the National Academy of Sciences of the USA 101:12579-12582.

Roubik, D. W. 2002. Tropical agriculture: the value of bees to the coffee harvest. Nature 417:708.

Schroth, G., G. A. B. da Fonseca, C. A. Harvey, C. Gascon, H. L. Vasconcelos, and A.-M. N. Izac, editors. 2004. Agroforestry and biodiversity conservation in tropical landscapes. Island Press, Washington D.C., USA.

SICA. 2003. Estadísticas Agropecuarias. Precios Finca y Rendimientos. Ministerio de Agricultura y Ganadería. Quito, Ecuador.

Southwick, E. E., and L. Southwick Jr. 1992. Estimating the economic value of honey bees (Hymenoptera: Apidae) as agricultural pollinators in the United States. Journal of Economic Entomology 85(3):621-633.

Tscharntke, T., A. M. Klein, A. Kruess, I. SteffanDewenter, and C. Thies. 2005. Landscape perspectives on agricultural intensification and biodiversity-ecosystem service management. Ecology Letters 8:857-874.

Zeller, M., S. Schwarze, and T. van Rheenen. 2002. Statistical sampling frame and methods used for the selection of villages and households in the scope of the research program on stability of tropical rainforest margins in Indonesia (STORMA). STORMA Discussion Paper Series Subprogram A (SDPS-A), number 1. Göttingen, Germany, and Bogor, Indonesia. 